\title{
The effect of using polypropylene fibers on the durability and fire resistance of concrete
}

\author{
Hassan Suiffi, Anas El Maliki \\ Control and Mechanical Characterization of Materials and Structure Laboratory (LCCMMS); National Higher School of \\ Electricity and Mechanics, BP 8118 Oasis, Hassan II, Casablanca, Morocco \\ bassane.suiffi@ensem.ac.ma;a.elmaliki@ensem.ac.ma \\ Fatima Majid \\ Laboratory of Nuclear, Atomic, Molecular, Mechanical and Energetic Physics, FSJ, University Chouaib Doukkali, El Jadida, \\ Morocco. \\ majidfatima9@gmail.com
}

\section{Omar Cherkaoui}

Laboratory on textile materials REMTEX, ESITH, Higher School of Textile and Clothing Industries Casablanca, BP 7731, Casablanca, Morocco

cherkaoni@esith.ac.ma

\begin{abstract}
In order to study the effect of polypropylene fibers on the durability of cementitious composites, several experimental tests have been carried out in the laboratory. The composite was tested with different volume fractions of polypropylene fibers $(0.05 \%, 0.10 \%, 0.30 \%$ and $0.50 \%)$. All the results relating to the indicators (porosity accessible to water $\varepsilon b$, to the oxygen permeability Kapp.gas and diffusivity Dns) indicate that the addition of polypropylene fibers in a cement matrix represents only a small effect on durability. This panel of general sustainability indicators can be supplemented by indicators more specific to each degradation process identified or envisaged depending on the environmental conditions of the structure. However, for fire resistance, concrete mixes are prepared using different volume fractions of polypropylene fibers $(0.05 \%, 0.10 \%, 0.30 \%$ and $0.50 \%)$, samples are heated to 300 and $600^{\circ} \mathrm{C}$, for exposures up to 6 hours, and tested for compressive strength. Based on the results of the study, it is concluded that the relative compressive strengths of concretes containing PP fibers were higher than those of concretes without PP fibers. In addition, it can be concluded that concrete mixes which are prepared using $0.50 \% \mathrm{PP}$ fibers, by volume, can significantly promote residual compressive strength during heating.
\end{abstract}

KEYwORDs. Polypropylene fibers; Porosity; Permeability; Diffusivity; Durability; Fire resistance.

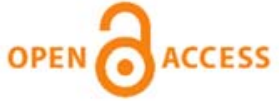

Citation: Suiffi, H., El Maliki, A., Majid, F., Cherkaoui, O., The effect of using polypropylene fiberson the durability and fire resistance of concrete, Frattura ed Integrità Strutturale, 58 (2021) 296-307.

Received: 10.07 .2021

Accepted: 03.09.2021

Published: 01.10.2021

Copyright: (C) 2021 This is an open access article under the terms of the CC-BY 4.0, which permits unrestricted use, distribution, and reproduction in any medium, provided the original author and source are credited. 


\section{INTRODUCTION}

$\mathrm{N}$ owadays, the addition of fibers to a cement matrix is a technique to be explored in the field of polymer reinforced materials [1-4]. In the construction and civil engineering sector, these composites are distinguished from other composite materials intended for industry and transport, by the variety of types of matrices and fibers, as well as by the different types of additions (mineral particles, synthetic powders or chemical agents), making a wide range of combinations or mixtures possible.

With the diversity of composite products in construction, it is becoming increasingly difficult to compare their properties and performance to construction or rehabilitation needs, which must meet several structural, thermal, economic and environmental criteria and requirements [5-8].

The inclusion of fibers in a concrete composite can be in the form of textile fabrics, or randomly dispersed in the matrix. Nevertheless, the use of dispersed fibers has been more evident for economic reasons. Among the different types of discrete fibers, steel fibers, but also polypropylene fibers have been widely used [9-11]. Both are generally used as secondary reinforcement in concrete, controlling the opening and propagation of cracks. Steel fibers can also be used as the main reinforcement. But they are sensitive to corrosion degradation and therefore influence the durability of the composite. Polymer fibers are an alternative to the use of steel fibers due to their chemical resistance and higher durability in cementitious matrices [12].

Nowadays, important work is devoted to the development of new approaches to the durability of concrete, in fact, by combining the measurement of the diffusion coefficient of chlorides and the gas permeability with others (such as in particular the determination of porosity, resistance to freeze-thaw cycles, etc.), it is thus possible to have various methods available to design concretes capable of protecting reinforced concrete structures against a given degradation (corrosion of reinforcements or alkaline reaction), for a lifetime and under given environmental conditions [13].

Research studies on the fire resistance of fiber composites [14] reported that the relative compressive strengths of concretes containing polypropylene fibers were higher than those of concrete without PP fibers, for temperatures up to at $600^{\circ} \mathrm{C}$. Komonen and Penttala [15] studied the effect of high temperature on residual properties a composite reinforced with polypropylene fibers with cement paste exposed to temperature up to $700{ }^{\circ} \mathrm{C}$. It is concluded that polypropylene fibers decrease compressive strengths and improve fire resistance.

Over time, a cement matrix structure must resist various aggressions or stresses (physical, mechanical, chemical, etc.), it can be subjected to various actions such as wind, rain, cold, heat, ambient environment, while maintaining its aesthetics. It must meet the needs of users at a constant level during its lifetime.

Durability is directly linked to the immediate or future environment of the structures and is today the important parameter to consider in order to optimize the resistance of concrete to external influences: bad weather, soil aggressiveness, and chemically aggressive atmospheres [16]. It is one of the critical issues that can affect concrete structures, especially as the issue of durability becomes more and more important. Permeability is considered to be the most important indicator for the long-term performance of a reinforced concrete structure [17,18]. Micro structural properties such as the size, distribution and interconnection of micro cracks and pores are the main factors that affect the permeability of concrete [19].

Even today, it is clear that few studies have been devoted to the durability of cementitious composites using the inclusion of polypropylene fiber. The study of the effect of adding these fibers on durability is certainly necessary and very useful to promote their uses in the building and civil engineering fields.

The aim of this work is to study the influence of the addition of polypropylene fibers in a cement matrix on the durability and fire resistance of the composite. This article is organized into several sections. the first section presents the characteristics of the materials used (gravel, cement and fibers, etc.), and the preparation of the formulation of the composites according to the different percentages of fibers $(0.05 \%, 0.10 \%, 0.30 \%$ and $0.50 \%)$.

The experimental program with the necessary laboratory tools is described in the next section. a chapter deals with the description of the laboratory test equipment, with the procedure followed to perform the tests according to the standards for each indicator of durability and fire resistance. In the results section, laboratory tests were presented in the form of graphs and curves with analysis and comments. Finally, the conclusion summarizes the main results related to the durability of the cementitious composite and the identification of the best fiber composition in the cement matrix in terms of fire resistance as well as its benefits and future prospects. 


\section{MATERIALS AND METHOD}

\section{Sand composition}

he sand used is normal sand. It comes from the quarries of the city of Kenitra (Morocco). The maximum size of GI lightweight aggregates is $16 \mathrm{~mm}$ and the maximum size of normal GII aggregates is $20 \mathrm{~mm}$.

\section{Cement composition}

The type of cement used is the product Lamaalem35®, a Portland cement composed of class CPJ 35 as defined by standard NM 10.1.004. This cement is obtained by grinding clinker, gypsum and other constituents. It has an onset of setting at $20{ }^{\circ} \mathrm{C}$ measured on a pure paste, which only appears after 1 hour 30 minutes with a hot expansion of less than $10 \mathrm{~mm}$ and shrinkage after 28 days measured on a normal mortar of less than $800 \mu \mathrm{m} / \mathrm{m}$.

\section{Concrete formulation with polypropylene fibers}

The composition of the concrete used is a cement matrix made up of gravel GI and GII from the Kenitra quarries, sand, cement, water and an appropriate NANOMENT HP 2038 admixture, for an overall density of $2417 \mathrm{~kg} / \mathrm{m}^{3}$, see Tab. 1 .

\begin{tabular}{|c|c|c|c|c|c|c|c|c|}
\hline & Water & Cement & Sand & $\begin{array}{c}\text { Coarse } \\
\text { aggregates } \\
\text { GI }\end{array}$ & $\begin{array}{c}\text { Coarse } \\
\text { aggregates } \\
\text { GII }\end{array}$ & admixture & $\begin{array}{c}\text { PP by } \\
\text { volume } \\
\text { of } \\
\text { concrete }\end{array}$ & $\begin{array}{c}\text { PP by } \\
\text { weight of } \\
\text { concrete }\end{array}$ \\
\hline & Liters & $\mathrm{kg} / \mathrm{m}^{3}$ & $\mathrm{~kg} / \mathrm{m}^{3}$ & $\mathrm{~kg} / \mathrm{m}^{3}$ & $\mathrm{~kg} / \mathrm{m}^{3}$ & $\mathrm{~kg} / \mathrm{m}^{3}$ & $\%$ & $\mathrm{~kg} / \mathrm{m}^{3}$ \\
\hline $\begin{array}{l}\text { Sample } \\
\text { concrete }\end{array}$ & 185 & 350 & 865 & 492 & 522 & 1.4 & 0 & 0 \\
\hline $\begin{array}{c}\text { Concrete with } \\
0.05 \% \mathrm{PP}\end{array}$ & 185 & 350 & 865 & 492 & 522 & 1.4 & 0.05 & 0.45 \\
\hline $\begin{array}{c}\text { Concrete with } \\
0.10 \% \mathrm{PP}\end{array}$ & 185 & 350 & 865 & 492 & 522 & 1.4 & 0.10 & 0.90 \\
\hline $\begin{array}{c}\text { Concrete with } \\
0.30 \% \mathrm{PP}\end{array}$ & 185 & 350 & 865 & 492 & 522 & 1.4 & 0.30 & 2.70 \\
\hline $\begin{array}{c}\text { Concrete with } \\
0.50 \% \mathrm{PP}\end{array}$ & 185 & 350 & 865 & 492 & 522 & 1.4 & 0.50 & 4.50 \\
\hline
\end{tabular}

Table 1: Composition of concrete with polypropylene fibers

In this experimental part, four concrete formulations with volume percentages of addition of polypropylene ranging from $0.05 \%, 0.10 \%, 0.30 \%$ and $0.50 \%$ were prepared for each fiber. A formulation of a control concrete without fiber is included for comparison.

\section{Fiber used}

The fiber used is a polypropylene fiber (Fig..1). It is manufactured by the SIKA company and fibrillated in pre-dosed pulp bags.

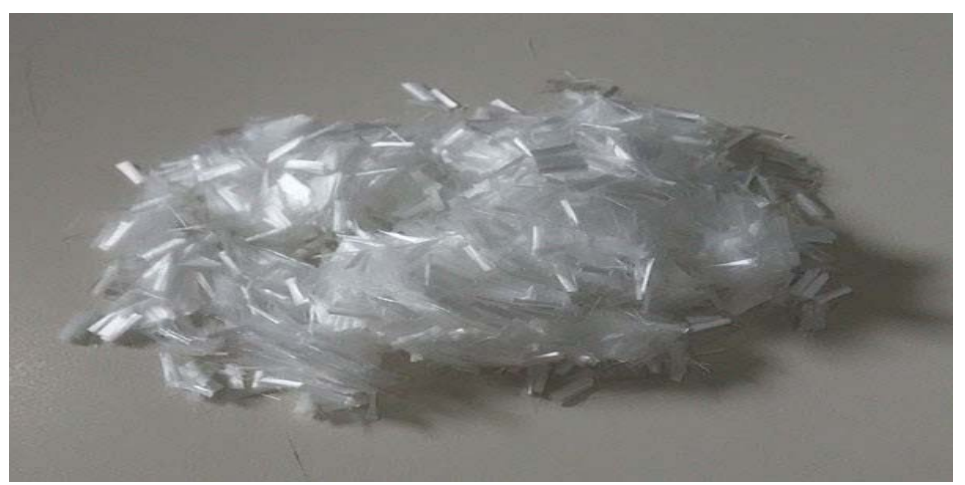

Figure 1: Polypropylene fiber (PP). 
The polypropylene fibers chosen for this study were selected from among the most widely used in the building and civil engineering markets. Data from the data sheet for these fibers are shown in Tab. 2.

\begin{tabular}{cc}
\hline Length (mm) & 12 \\
Specific Gravity & 0.91 \\
Diameter & $29 \mu \mathrm{m}$ \\
Melt Point & $160^{\circ} \mathrm{C}$ \\
Ignition Point & $590^{\circ} \mathrm{C}$ \\
Tensile strength & $400 \mathrm{MPa}$ \\
\hline
\end{tabular}

Table 2: Properties and technical data of the polypropylene fibers.

The development of the final composition of the fiber-reinforced concrete requires knowledge of the properties of the fibers used. The authors' interest has been focused on the influence of the nature of fibers on the mechanical and physicochemical behavior of composites. In this sense, a series of formulations with volume fractions of polypropylene (PP) fibers ranging from $0.05 \%$ to $0.50 \%$ was adopted in this study.

\section{EXPERIMENTAL PROGRAM}

$\mathrm{T}$ he experimental tests have been carried out at the level of the Public Testing and Studies Laboratory (LPEE). The $150 \mathrm{~mm} \times 300 \mathrm{~mm}$ cylindrical specimens were obtained by mixing gravel, cement and fiber, in accordance with standard NF P 18-470 [20]. The mixture is carried out in a standardized tilting drum mixer. At the start, 10\% of the mixing water is added with the aggregates. Then the remaining $90 \%$ of the mixing water is gradually added during the mixing process to the solid ingredients. The cement is added inside the mixer after about $10 \%$ of the aggregates have been loaded, while the polypropylene fibers are gradually added to the cement to have a more homogeneous mixture.

First, a raw concrete mix was prepared to be considered as a reference, as shown in Tab. 1. The same composition was retained for the concrete matrix in all mixtures with polypropylene fibers studied in the part of this research. For the preparation of the tests, cylindrical specimens of dimensions $16 \times 32 \mathrm{~cm}$ by $18 \times 3$ ( 3 for the raw concrete and 3 for each mixture of fiber-reinforced gravel) were carried out.

The tests are carried out on samples cored on test pieces stored in humidity $(\mathrm{RH}=50 \pm 10 \%)$ at an ambient temperature of $20^{\circ} \mathrm{C} \pm 2{ }^{\circ} \mathrm{C}$.

\section{TEST PROTOCOL}

\section{Durability indicators for fiber-reinforced concrete}

$\checkmark$ he objective of choosing sustainability indicators is to formalize a methodology for obtaining concrete capable of protecting structures against a given degradation, in particular within the contractual framework where it must meet a lifetime requirement. The approach is, based on the choice of a reduced number of durability indicators, key parameters in the quantification and prediction of the durability of concrete. These parameters are measured from laboratory tests on test tubes. The choice of these indicators (porosity, permeability and diffusivity) and the specification criteria (thresholds and classes) of acceptability of these parameters, depending on the type of environment considered constitute the main stages of the sustainability experimentation process.

First, the porosity test consists in measuring the open porosity $\varepsilon b$ which characterizes the ratio of the total volume of the open pores of the sample to its apparent volume. Specimens of the fiber composite having as diameter and height the following values (Ø100 mm H $50 \mathrm{~mm}$ ) (Fig. 2 (a)) and are obtained by mechanical coring on the cylindrical specimens $150 / 300 \mathrm{~mm}$. The procedure adopted is that recommended by standard NFP 18-459 [21]. The test consists of weighing the sample in air and then in a liquid of known density.

The test pieces are placed in a standardized vacuum desiccator, then we fill it with water until the test pieces are completely submerged for 48 hours. 
Next, we measure the $\mathrm{M}_{\text {water }}$ mass of the test tube in water using a submerged boat suspended from a balance according to the device shown in Fig. 2 (b).

After cleaning the sample, we carry out a second weighing to obtain the mass $\mathrm{M}_{\text {air, }}$ we end the test by placing the test piece in a ventilated oven at $105 \mathrm{C}^{\circ} \pm 5$ until a mass $\mathrm{M}_{\text {dry }}$ is obtained, and the process is stopped once the difference in measurement of two successive weighing at 24-hour intervals does not exceed $0.10 \%$.

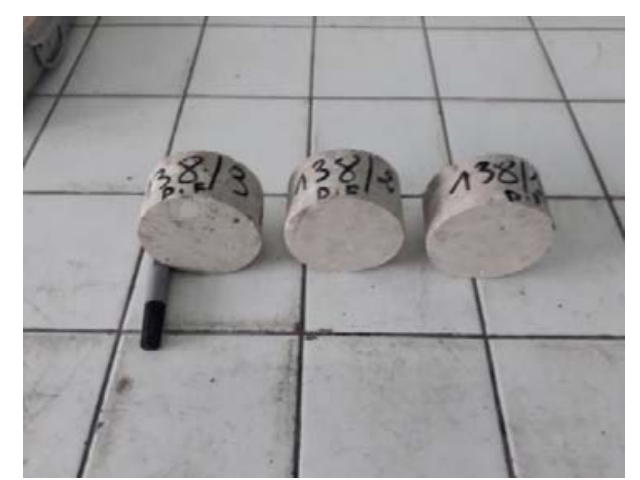

(a)

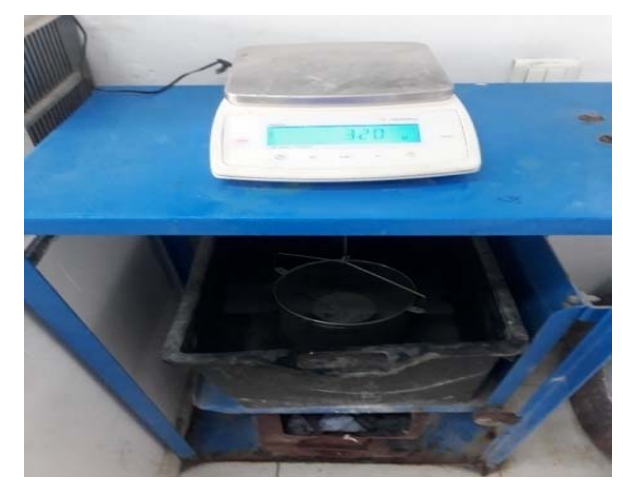

(b)

Figure 2: Porosity test (a) Three samples of the fiber-reinforced concrete (Ø100x $50 \mathrm{~mm}$ ) prepared; (b) Weighing the sample

The porosity accessible to water, $\varepsilon_{\mathrm{b} \text { moy }}$ is therefore given by Eqn. (1).

This is a laboratory method, applicable to molded and cored specimens of structures

$$
\varepsilon_{\mathrm{b} \text { moy }}=\frac{\mathrm{M}_{\text {air }}-\mathrm{M}_{\mathrm{dry}}}{\mathrm{M}_{\text {air }}-\mathrm{M}_{\text {water }}} .100
$$

Second, the gas permeability test is carried out with a constant load permeameter as recommended by CEMBUREAU [22]. Its purpose is to measure the oxygen permeability (in $\mathrm{m}^{2}$ ) of concrete test bodies, hardened, this is a laboratory method, applicable to molded and cored test pieces of structures, within the limits of the dimensional tolerances imposed by the measuring cells of the device.

The test consists in subjecting a cylindrical specimen to a constant pressure gradient (Fig. 3). The apparent permeability ( $\mathrm{K}_{\text {app.gas }}$ ) is determined, according to standard XP P18-463 [23]. From the measurement (Fig. 3) of the flow in steady state with the assumption of a laminar flow at a given pressure using the law of Hagen-Poiseuille below (2):

$$
\mathrm{K}_{\text {app.gas }}=\frac{2 \cdot \mathrm{Q} \cdot \mathrm{P}_{\text {atm }} \cdot \mathrm{L} \cdot \mu}{\mathrm{A}\left(\mathrm{P}_{\mathrm{o}}^{2}-\mathrm{P}_{\text {atm }}^{2}\right)}
$$

Where:

Q: volume flow in $\mathrm{m}^{3} / \mathrm{s}$,

$\mathrm{P}_{\text {atm: }}$ atmospheric pressure in $\mathrm{Pa}$,

L: thickness of the sample in $m$,

A: section of the test body in $\mathrm{m}^{2}$,

$\mathrm{P}_{\mathrm{o}}$ : absolute inlet pressure in $\mathrm{P}_{\mathrm{a}}$,

$\mu$ : dynamic viscosity of oxygen at $20^{\circ} \mathrm{C}$ in $\mathrm{Pa} \cdot \mathrm{S}$.

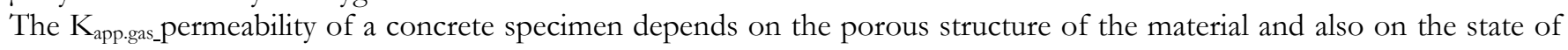
the water in the specimen. The permeability increases as the average water saturation rate of the test piece decreases. To determine the permeability of a concrete, it is therefore necessary, on the one hand, to at least partially dry the test specimen intended for the measurement so that the gas can pass through this test specimen, and on the other hand, to know the average saturation rate or even the distribution of the water content in the test piece, corresponding to the measured permeability. 


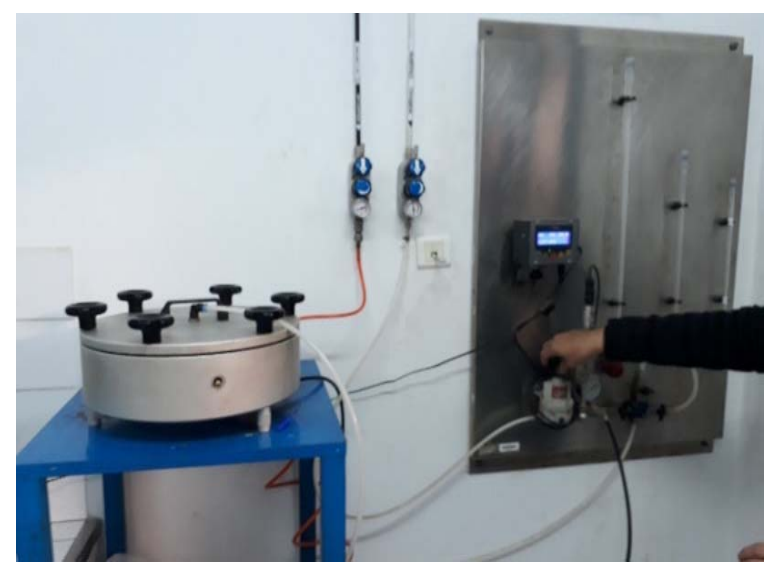

Figure 3: Inflation of the chamber to 8 bars and Measurement of oxygen permeability

For the diffusivity, the objective is to determine the diffusion coefficient of the chloride ionsDns, following a test in saturated conditions of migration under an electric field in non-stationary mode according to the standard XP P 18-462 [24]inspired by the Danish standard " Nord Test Method «Standard NTB 492 [25]. For each fiber composition, three concrete samples are subjected to an accelerated diffusion test (see the experimental device in Fig. 4) with chloride ions according to the following principle: one sample (test tube $\varnothing 100 \mathrm{~mm} \mathrm{H} 50 \mathrm{~mm}$ ) within the meaning of standard NF EN 206-1 [26] saturated one and a half months with water is placed between two upstream and downstream compartments.

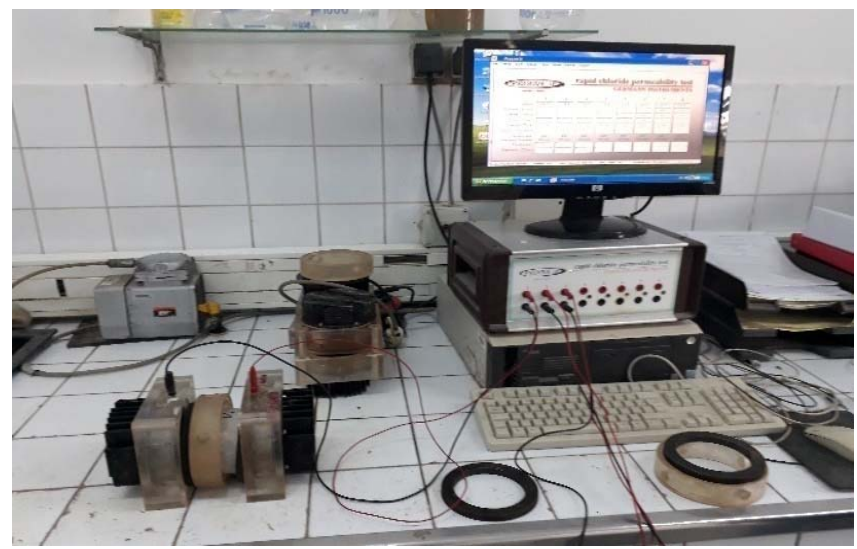

Figure 4: Device for Chloride diffusion test.

At the end of the test set-up, the sample is cut parallel to its axis. A section is covered with a solution of silver nitrate to determine the depth of penetration of chloride ions (see Fig. 5).

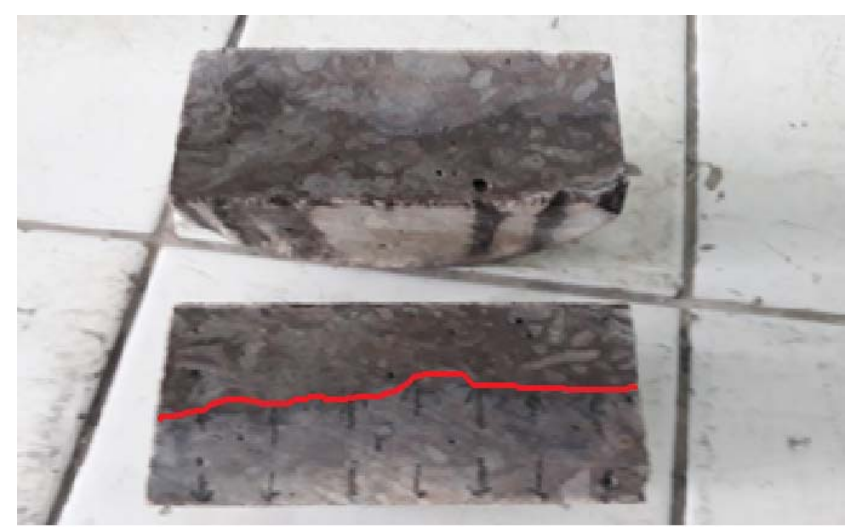

Figure 5: Depth of penetration of chloride ions in the sample. 
The diffusion coefficient in non-stationary regime $\mathrm{D}_{\text {moy }}$ is calculated according to formula (3):

$$
\mathrm{D}_{\text {moy }}=\frac{0.0239 \cdot(273+\mathrm{T}) \cdot \mathrm{L}}{(\mathrm{U}-2) \cdot \mathrm{t}} \cdot\left\{\mathrm{X}_{\mathrm{d}}-0.0238 \sqrt{\frac{(273+\mathrm{T}) \cdot \mathrm{L} \cdot \mathrm{X}_{\mathrm{d}}}{(\mathrm{U}-2)}}\right\}
$$

where:

$\mathrm{U}:$ potential difference applied in volts,

T: average temperature of the solution in ${ }^{\circ} \mathrm{C}$,

L: specimen thickness in $\mathrm{mm}$,

$\mathrm{X}_{\mathrm{d}}$ : average value of the penetration depth of chloride ions in $\mathrm{mm}$,

t: test duration in hours.

\section{Fire resistance}

Regarding this component, the objective is to study the effect of polypropylene fibers on the fire resistance of the concrete composite. Concrete mixes are prepared using volume fractions $0.05 \%, 0.10 \%, 0.30 \%$ and $0.50 \%$ polypropylene fibers. In order to take into account, the accuracy of the test result, three specimens were prepared from each group of concrete mixes. After the sample curing period, each group was exposed to 300 and $600^{\circ} \mathrm{C}$ on a standard electric oven for 2 hours, 4 hours and 6 hours. After the step of cooling the samples inside the oven, the compressive strength of the specimens was measured by the "CONTROLS" uniaxial press model 82-0331/2 according to the EN standard. N.12390-3 [27].

\section{RESULTS AND DISCUSSION}

he results of durability indicators (porosity, gas permeability and diffusivity) of laboratory samples in a cured state according to the different volume fractions of polypropylene fibers are presented in Tab. 3.

\begin{tabular}{ccccc}
\hline & Porosity $\varepsilon_{\text {bmoy }} \%$ & $\begin{array}{c}\text { Volumic mass @a } \\
\text { in }\left(\mathrm{g} / \mathrm{cm}^{3}\right)\end{array}$ & $\begin{array}{c}\text { Gas permeability } \\
\mathrm{K}_{\text {app.gas }}\left(10^{-18} \mathrm{~m}^{2}\right)\end{array}$ & $\begin{array}{c}\text { diffusivity } \\
\mathrm{D}_{\text {moy }} 10^{-12} \mathrm{~m}^{2} / \mathrm{S}\end{array}$ \\
Sample concrete & 13.20 & 2.47 & 97.30 & 5.90 \\
Concrete with $0.05 \% \mathrm{PP}$ & 13.30 & 2.38 & 97.80 & 6.00 \\
Concrete with $0.10 \% \mathrm{PP}$ & 13.50 & 2.30 & 98.60 & 6.20 \\
Concrete with $0.30 \% \mathrm{PP}$ & 13.70 & 2.19 & 98.40 & 6.20 \\
Concrete with $0.50 \% \mathrm{PP}$ & 13.80 & 2.19 & 98.90 & 6.40 \\
\hline
\end{tabular}

Table 3: Concrete durability indicator test results with polypropylene

\section{Effect of PP fibers on the porosity of the composite}

At the reference state $\left(105^{\circ} \mathrm{C}\right)$, the porosity of the different cementitious matrices with different volume fractions of polypropylene fibers is almost equivalent and close to $13.2 \%$ (13.3\% minimum for the composite with polypropylene fibers). With the increase in the dosage of polypropylene fibers, the porosity increases slightly by $4.55 \%$ (Tab. .3) on average compared to non-fibrous concrete (see Fig. 6). This is explained by the fact that the presence of these polypropylene fibers in a cementitious composite causes the interconnectivity of the pores of the composite with the concrete and consequently an increase in the pore volume. But this porosity remains low compared to other matrices with other types of fibers (metallic, synthetic, etc.); in the case of steel fibers [28], a study showed that the addition of these fibers with a length of $30 \mathrm{~mm}$, did not affect the porosity when the volume fraction varied from 0.50 to $1 \%$ but, beyond $1 \%$, there was a slight increase in porosity. 
With increasing temperature, the porosity of concrete with polypropylene fibers increases faster than that of concrete without fibers. This increase in porosity is very probably related to the channels formed after the fusion of the fibers in accordance with previous studies [29, 30].

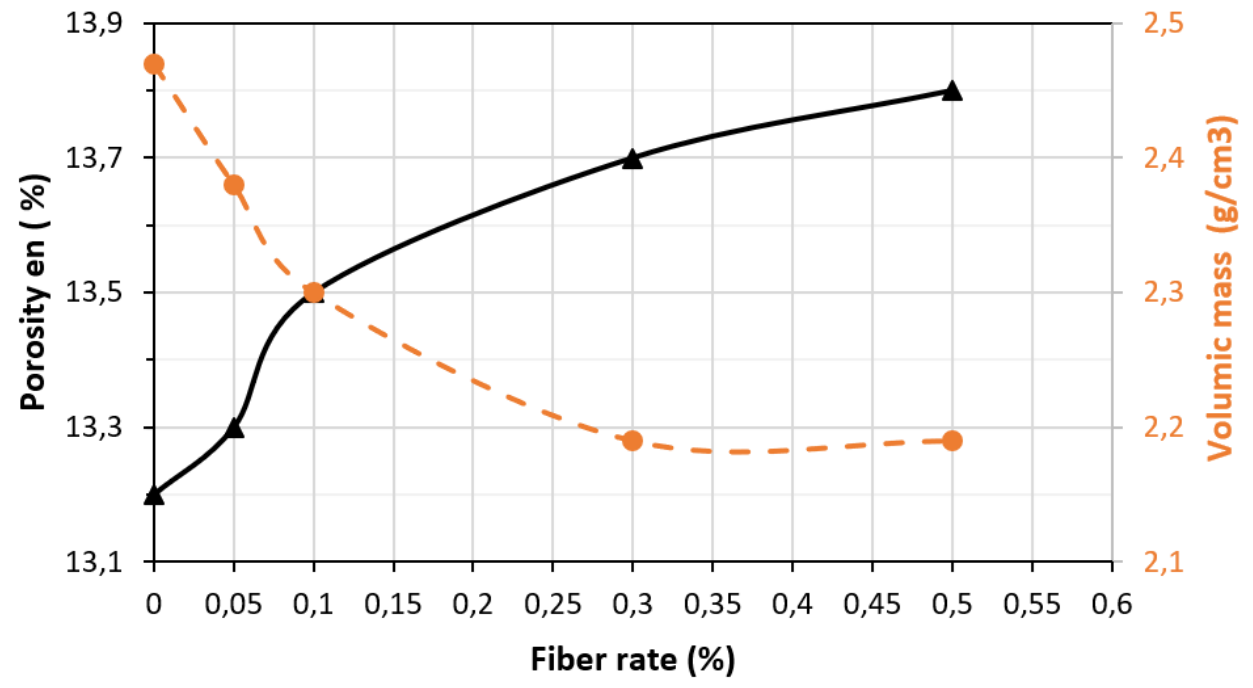

Figure 6: Evolution of porosity with addition of fibers

\section{Effect of PP fibers on the gas permeability of the composite}

The gas permeability of the various non-fibrous and fibrous matrices is equivalent, close to $97.3 \mathrm{E}-18 \mathrm{~m}^{2}\left(97.8 \mathrm{E}-18 \mathrm{~m}^{2}\right.$ minimum for the composite with polypropylene fibers). With a dosage of polypropylene fibers of $0.10 \%$, the gas permeability increases by $1.34 \%$ on average compared to concrete without fibers (see Fig. 7 ).

All the concrete compositions have a relatively low intrinsic permeability of the order (98 E- $\left.18 \mathrm{~m}^{2}\right)$. It can be seen that concrete without fibers $\left(97.3 \mathrm{E}-18 \mathrm{~m}^{2}\right)$ generally has permeability close to those containing polypropylene fibers (98.6 \pm $1.10 \mathrm{E}-18 \mathrm{~m}^{2}$ ). According to Fig. 7, we notice a small increase in permeability as the volume factions of polypropylene fibers are increased; this increase is still very low and places the fiber-reinforced concrete in the same group as concrete without fiber.

This slight increase in the permeability of the composite is justified by the fact that the flow network which conditions the passage of a gas through the fiber-reinforced concrete is clearly coarser than that represented by the capillary porosity of its hydrated cement paste [31], under the effect of extreme degradation, the concrete loses its strength and the presence of micro cracks facilitates the passage of a gas through the networks of capillary pores connected due to the presence of fibers in the concrete matrix.

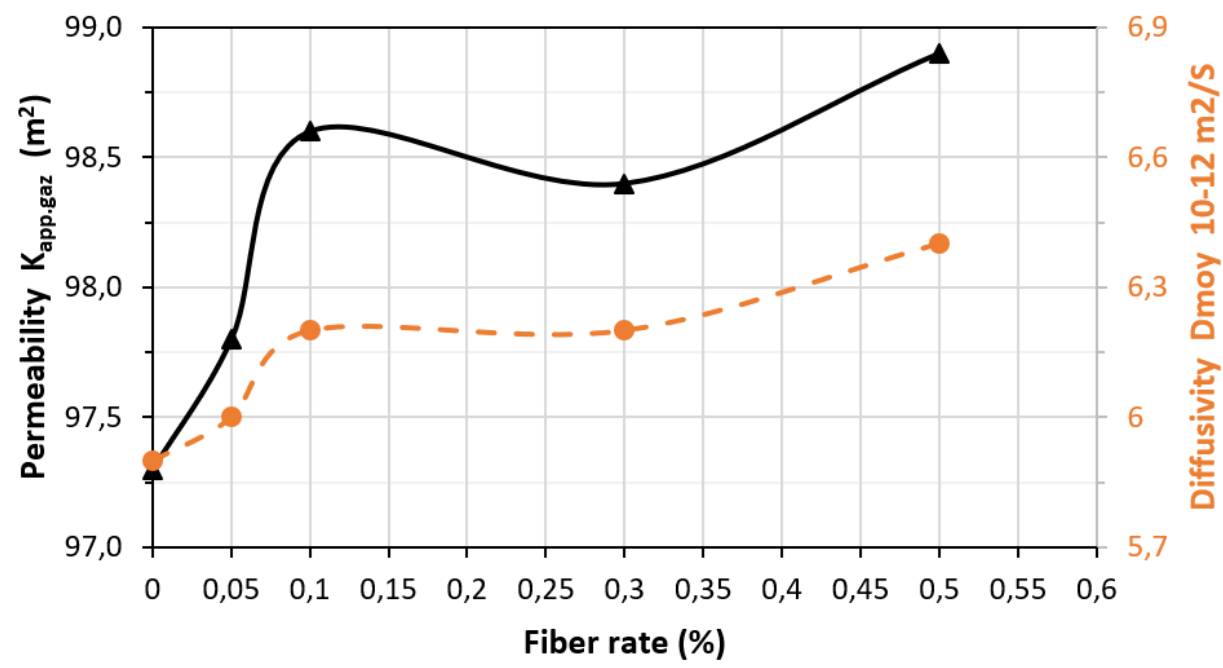

Figure 7: Evolution of permeability with addition of fibers 


\section{Effect of PP fibers on the diffusivity of the composite}

The chloride ion penetration tests in the sample of the various cement matrices containing polypropylene fibers show that there is little difference compared to the control concrete without fiber. The diffusivity values are close to $6.2 \cdot 10^{-12} \mathrm{~m}^{2} / \mathrm{s}$ (as minimum value for the composite with $0.05 \%$ polypropylene fibers). Similarly, to permeability, there is a slight increase in diffusivity with the dosage of $0.10 \%$ polypropylene fibers, approaching $7.25 \%$ on average compared to non-fiber concrete (see Fig. 7). This is explained by the low absorption rate of polypropylene fibers.

These results are in line with research done by Antoni [32] who studied the effect of chloride penetration and found the effect to be insignificant for short polypropylene fibers identical to those used in this research.

At the end of these results, the durability indicators examined remain within the same range of normal concrete, which gives the cement matrix with polypropylene fibers an almost identical durability to concrete without fibers, which favors its use in more specific cases in the building sector.

\section{Effect of PP fibers on the fire resistance of the composite}

Laboratory tests have been carried out on samples prepared for this purpose, the results of the compressive strength (hardened state) of the various samples exposed to temperatures of 300 and $600^{\circ} \mathrm{C}$, and according to the volume fractions $0.05 \%, 0.10 \%, 0.30 \%$ and $0.50 \%$ polypropylene fibers are shown in Tab. 4 .

\begin{tabular}{|c|c|c|c|c|c|c|c|}
\hline \multirow[t]{2}{*}{ Fiber dosage } & \multirow{2}{*}{$\begin{array}{c}\text { Compressive } \\
\text { strength } \\
(\mathrm{MPa}) \\
\text { At } 23^{\circ} \mathrm{C}\end{array}$} & \multicolumn{3}{|c|}{$\begin{array}{l}\text { Reduction (Compressive strength) in } \% \text { at } \\
300^{\circ} \mathrm{C}\end{array}$} & \multicolumn{3}{|c|}{$\begin{array}{l}\text { Reduction (Compressive strength) in } \% \text { at } \\
6000^{\circ} \mathrm{C}\end{array}$} \\
\hline & & 2 hours & 4 hours & 6 hours & 2 hours & 4 hours & 6 hours \\
\hline Without fiber & 30.25 & 17.60 & 26.50 & 33.54 & 19.45 & 28.05 & 36.58 \\
\hline $0.05 \% \mathrm{PP}$ & 30.80 & 18 & 26.80 & 33.12 & 19.95 & 28.10 & 36.12 \\
\hline $0.10 \% \mathrm{PP}$ & 31.40 & 19.60 & 27.30 & 32.00 & 20.45 & 28.30 & 34.00 \\
\hline $0.30 \% \mathrm{PP}$ & 34.33 & 20.10 & 25.35 & 29.65 & 22.55 & 26.50 & 29.54 \\
\hline $0.50 \% \mathrm{PP}$ & 34.50 & 16.45 & 17.90 & 21.50 & 19.00 & 19.60 & 24.25 \\
\hline
\end{tabular}

Table 4: Compressive strength test results with PP fibers under different temperatures.

The maximum compressive strength at $23{ }^{\circ} \mathrm{C}$ was determined for the $0.50 \%$ polypropylene fiber composite and this increase was approximately $14 \%$ compared to the non-fiber control concrete samples, for the test pieces heated to $300{ }^{\circ} \mathrm{C}$ we see that the compressive strength of concrete without fibers has undergone a reduction from $17.6 \%$ to $33.54 \%$ against 16.45 to $21.5 \%$ compared to concrete with $0.50 \%$ fibers, and from $19.45 \%$ to $36.58 \%$ against $19 \%$ at $24.25 \%$ for test pieces heated to $600^{\circ} \mathrm{C}$, this is in line with studies [33, 34] made by researchers on the fire resistance of composites with polypropylene fibers.

For temperatures of 300 and $600{ }^{\circ} \mathrm{C}$, the composite with $0.50 \%$ fibers exhibits the least loss in compressive strength, this loss is increased at 6 hours of exposure for the two temperature ranges, the fiber-reinforced concrete at $0.50 \%$ gains approximately $15.44 \%$ in $300{ }^{\circ} \mathrm{C}$ and approximately $14.58 \%$ in $600{ }^{\circ} \mathrm{C}$.

Analysis of the curves in Fig. 8 (a) and (b) shows that the compressive strength of the $0.50 \%$ polypropylene fiber composite remains close to $27 \mathrm{MPa}$ compared to $20 \mathrm{MPa}$ for non-fiber concrete.

This is because when fiber less concrete is exposed to fire, heat penetrates the concrete, which results in moisture desorption in the outer layer. Moisture vapors flow back to the cold interior and are reabsorbed in the voids. Water and steam build up inside, increasing the steam pressure, quickly causing cracks and splinters in the concrete.

In the case of concrete containing polypropylene fibers, the fibers melt at $160^{\circ} \mathrm{C}$ creating voids in the concrete. Vapor pressure is released in the newly formed voids and explosive spalling is greatly reduced [35].

This observation is corroborated by the studies of certain researchers $[36,37]$, who announce that the inclusion of polypropylene fibers in concrete, manages to reduce or prevent the phenomenon of bursting which occurs in concrete, 
during the heating and under the effect of very high temperatures the fibers decompose without producing harmful gases, this helps to create spaces which act as escape routes, thus reducing the pressure in the pores.

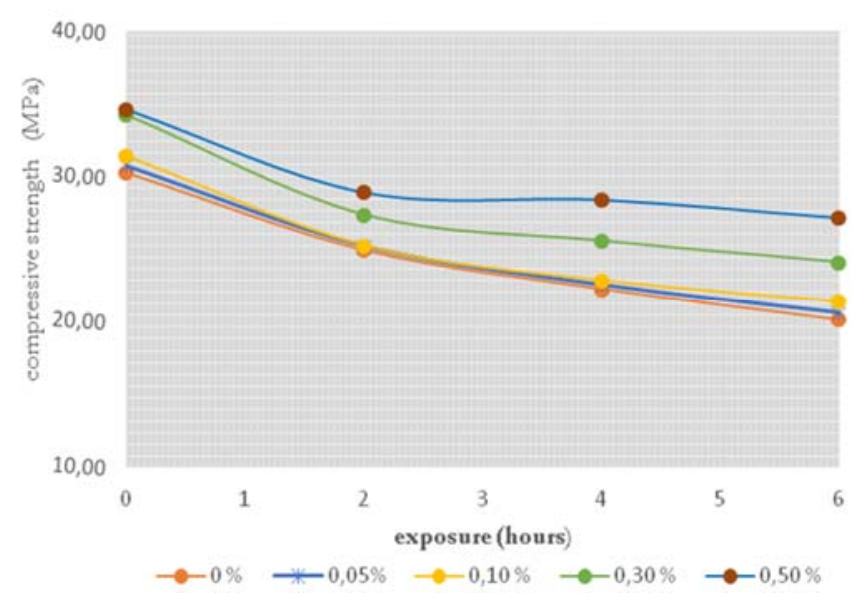

(a)

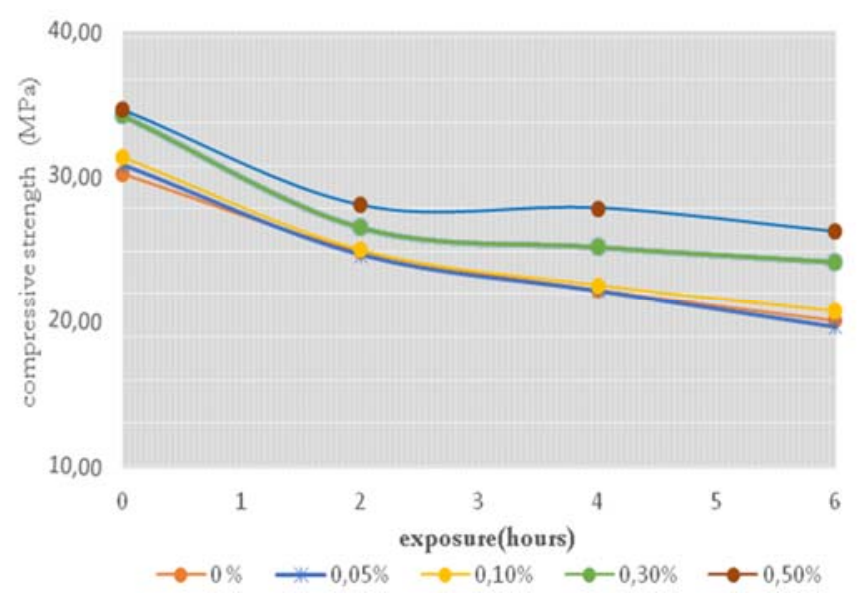

(b)

Figure 8: Evolution of compressive strength (a) at $300^{\circ} \mathrm{C}$, (b) at $600^{\circ} \mathrm{C}$.

\section{CONCLUSION}

$\mathrm{W}$

hen concrete degrades under the influence of external agents, the existence of cracks allows liquids and chemical particles to penetrate into the composites and accelerate the deterioration of structures. To improve the ductility and durability of the composite and prevent the formation of cracks in the concrete components, we considered reinforcing them with polypropylene fibers to reduce the entry of harmful particles into the concrete elements.

The results obtained in this study show an insignificant increase in porosity, permeability and a small acceleration of the infiltration of chemical agents compared to concrete without fibers, this could be explained by the presence of connected pores created by the existence of polypropylene fibers inside the composite. With the incorporation of polypropylene fibers into the cement matrix, the composite remains durable and can be used in specific applications depending on the degradation process envisioned and depending on the environmental conditions of the structure.

Under conditions of very high temperatures, the use of polypropylene fibers in the cement matrix reduces the effect of spalling and bursting of the concrete and consequently improves its durability, the optimal percentage of polypropylene to be used in the concrete for improving fire resistance is about $0.50 \%$ by volume fraction.

This study using durability indicators revealed that concrete containing polypropylene fibers is in the same family as ordinary concrete in terms of durability but acquires better resistance in terms of fire resistance and therefore has some potential. in the civil engineering market.

\section{NOMENCLATURE}

$\begin{array}{llll}\varepsilon_{\mathrm{b}} & \text { porosity } & \mathrm{L} & \text { thickness of the sample } \\ \mathrm{K}_{\text {app.gas }} & \text { gas permeability } & \mathrm{A} & \text { section of the test body } \\ \mathrm{D}_{\text {RNS }} & \text { diffusivity } & \mathrm{P}_{\mathrm{o}} & \text { absolute inlet pressure } \\ \mathrm{M}_{\text {air }} & \text { air density } & \mu & \text { dynamic viscosity of oxygen } \\ \mathrm{M}_{\text {dry }} & \text { dry air density } & \mathrm{U} & \text { potential difference applied } \\ \mathrm{M}_{\text {water }} & \text { density in water } & \mathrm{T} & \text { temperature of the solution } \\ \mathrm{Q} & \text { volume flow } & \mathrm{X}_{\mathrm{d}} & \text { value of the chloride penetration } \\ \mathrm{P}_{\mathrm{atm}} & \text { atmospheric pressure } & \mathrm{t} & \text { test duration in hours }\end{array}$




\section{ACKNOWLEDGEMENTS}

he authors express their sincere thanks to the heads of the Public Testing and Studies Laboratory (LPEE) of
TiTMelil, Casablanca, Morocco and more particularly Mr. Ouali A. for carrying out the tests.

\section{REFERENCES}

[1] Regilan, M., Silva, D, (2013). Dominguez and all, Characterization of Lightweight Cementitious Composites Reinforced with Piassava Fibers Using Mechanical Tests and Micro-Tomography, International Review of Chemical Engineering (I.RE.CH.E), 5(6), pp. 2035-1755.

[2] Kaarthik, N. K. (2018). Enhancement of properties of concrete using natural fibers, Materials today Proceedings, 5(11), 3, pp. 23816-23823. DOI: 10.1016/j.matpr.2018.10.173.

[3] Formisano. A., Galzerano. B., Durante, M., Ottavio, M., Liguori, B.. (2018). Mechanical Response of Short Fiber Reinforced Fly Ash Based Geopolymer Composites, International Review of Mechanical Engineering (IREME), 12(6), pp. 485-491. DOI: org/10.15866/ireme.v12i6.14826

[4] Bashar, B., Ahamad, A. (2019). Properties of Fiber-Reinforced Structural and Non-Structural Ultra Lightweight Aggregate Concrete, International Review of Civil Engineering (IRECE), 10(5), pp. 227-234.

DOI: $10.15866 /$ irece.v10i5.16971.

[5] Chanvillard, G. (1993). Experimental analysis and micromechanical modeling of the behavior of wiredrawn steel fibers, anchored in a cementitious matrix, Etude et recherche du LPC.

[6] Martijn, L., M., Stijn, N., Cok, B., Worrell, E., Shen, L. (2017). Life cycle assessment of sisal fibre - Exploring how local practices can influence environmental performance, Journal of Cleaner Production, 149(15), pp. 818-827. Elsevier. DOI: 10.1016/j.jclepro.2017.02.073

[7] Muhammad, A., Ghulam, M., Hafsa, J. (2020). Comparative experimental investigation of natural fibers reinforced light weight concrete as thermally efficient building materials, Journal of Building Engineering, 31, pp. 101411. DOI: $10.1016 /$ j.jobe.2020.101411.

[8] El Mabchour, F. E., Abouchadi, H., Zeriab Es-sadek, M., Taha-Janan, M. (2020). Theoretical and Numerical Contribution for Prediction of the Mechanical Properties of a Randomly Distributed Reinforcement in the Matrix, International Review of Mechanical Engineering (IREME), 14(5), pp. 1970-8734.

DOI: $10.15866 /$ ireme.v14i5.19150.

[9] Conforti, F., Minelli, G.A., Plizzari, G.(2018). Comparing test methods for the mechanical characterization of fiber reinforced concrete, Structural Concrete, 19(1), pp. 656-669. DOI: 10.1002/suco.201700057.

[10] Caggiano, A., Gambarelli, S., Martinelli, E., Nisticò, N., Pepe, M. (2016). Experimental characterization of the postcracking response in Hybrid Steel/Polypropylene Fiber-Reinforced Concrete, Construction and Building. Materials, 125, pp. 1035-1043. DOI: 10.1016/j.conbuildmat.2016.08.068.

[11] Yermak N., Pliya, P., Beaucour, A.L., Simon, A., Noumowé, A. (2017). Influence of steel and/or polypropylene fibers on the behavior of concrete at high temperature: spalling, transfer and mechanical properties, Construction and Building. Materials, 132, pp. 240-250. DOI: 10.1016/j.conbuildmat.2016.11.120.

[12] de Alencar, V. M., Monteiro, L. R., Lima, F. de Andrade, S. (2018). on the mechanical behavior of polypropylene, steel and hybrid fiber reinforced self-consolidating concrete, Construction and Building. Materials, 188(10), pp. 280291. DOI: 10.1016/j.conbuildmat.2018.08.103.

[13] Al-katib, H., Hayder, A. Haider, A. (2018). Behavior of polypropylene Fibers Reinforced Concrete Modified with High Performance, Cement, International Journal of Civil Engineering and Technology (IJCIET), 9(5), pp. 10661074. Available online at http:/ $/$ www.iaeme.com/ijciet/issues.asp?JType=IJCIET\&VType=9\&IType $=5$.

[14] Chen, B., Liu, J. (2004). Residual strength of hybrid-fiberreinforced high-strength concrete after exposure to high temperatures, Cement and Concrete Research, 34(6), pp. 1065-1069. DOI: 10.1016/j.cemconres.2003.11.010.

[15] Komonen, J., Penttala, V. (2003). Effects of high temperature on the pore structure and strength of plain and polypropylene fiber reinforced cement pastes, Fire Technology, 39(1), pp. 23-34. DOI: 10.1023/A:1021723126005.

[16] Lagrini, K., Ghafiri, A., Ouali, A. (2016). Morocco frost map contribution to the durability of concrete, Construction review, LPEE, N¹34, Available at: www.lpee.ma. 
[17] Shi, X., Xie, N., Fortune, K., Gong, J. (2012). Durability of steel reinforced concrete in chloride environments: An overview, Construction and Building. Materials, 30, pp. 125-138. DOI: 10.1016/j.conbuildmat.2011.12.038.

[18] Teng, S., Divsholi, B. S., Lim, T., Gjørv, O.E. (2014). Concrete with very high resistance to chloride ingress, Concr. Int, 36(5), pp.30-36. Available at:

http://www.concrete.org/publications/internationalconcreteabstractsportal.aspx?m=details\&i=51686931

[19]Zhang, M.H., Li, H. (2011). Pore structure and chloride permeability of concrete containing nano-particles for pavement, Construction and Building. Materials, 25(2), pp. 608-616. DOI: org/10.1016/j.conbuildmat.2010.07.032.

[20] The standard NF P 18-470. (July 2013). Concrete - Ultra High-Performance fiber concrete - Specification, performance, production and conformity.

[21] The standard NFP 18-459. (March 2010). Test for hardened concrete - Porosity and density test, ICS: 91.100.30.

[22] Kollek, J. J. (1989). The determination of the permeabilityof concrete to oxygen by the Cembureau method, a Recommendation, Materials and Structures, 22, pp. 225-230. DOI: org/10.1007/BF02472192.

[23] The standard XP P18-463, E. (2011). Concrete - Testing gas permeability on hardened concrete, ICS: 91.100.30.

[24] The standard XP P 18-462. (June 2012). Test on hardened concrete Accelerated ion migration testchloride in nonstationary regime: Determination of the apparent diffusion coefficient of chloride ions, ICS: 91.100.30.

[25] Danish standard "Nord test Method" NTB standard 492.

[26] Standard NF EN 206-1. (December 2012). Concrete - Part 1: specification, performance, production and conformity - National supplement.

[27] NF, EN, N, 12390-3. (2012). Tests for hardened concrete - Part3: compressive strength of the specimens, France.

[28] Miloud, B. (2005). Permeability and porosity characteristics of steel fiber reinforced concrete. Asian Journal of Civil Engineering, 6(4), pp. 317-330. Available at: Corpus id: 137743977.

[29] Noumowe, A., Lefèvre, A., Duval, R. (2002). Porosité supplémentaire consécutive à la fusion de fibres de polypropylène dans un béton à hautes performances. Revue Française de Génie Civil 6(2), pp. 301-313. DOI: org/10.1080/12795119.2002.9692366.

[30] Komonen, J., Penttala, V. (2003). Effects of High Temperature on the Pore Structure and Strength of Plain and Polypropylene Fiber Reinforced Cement Pastes, Fire Technology 39(1), pp. 23-34. DOI: 10.1023/A:1021723126005.

[31] Praton, D., Aitcin, P., Carles-Gibergue, A. (1999). Measurement of the gaseous permeability of concrete: Part I Validation of the Carman and Klinkenberg concepts in the case of a high-performance concrete (BHP), Bulletin des Laboratoires des Ponts et Chaussées, 221, REF, 4241, pp. 69-78. Available at: https://trid.trb.org/view/959607

[32] Honguchi, T., Saeki, N. (2003). Influence of stress on chloride penetration into fiber reinforced concrete, JCI, 25, pp. 779-784. Available at: Corpus ID: 55101444

[33] Chang, Y, F., Chen, Y., Sheu, M., Yao, G. (2006). Residual stress-strain relationship for concrete after exposure to high temperatures, Cements and Concrete Research, 36(10), pp. 1999-2005.

DOI: org/10.1016/j.cemconres.2006.05.029.

[34] Shihada, S. (2011). Effect of polypropylene fibers on concrete fire resistance, journal of civil engineering and management, 17 (2), pp. 259-264. DOI: 10.3846/13923730.2011.574454.

[35] Aulia, T, B. (2002). Effects of polypropylene fibers on the properties of high-strength concretes, LACER, 7, pp. 4359.

[36] Kalifa, P. Chéné, G. Gallé, C. (2001). High temperature behavior of HPC with polypropylene fibers from spalling to microstructure, Cement and Concrete Research, 31(10), pp. 1487-1499. DOI: org/10.1016/S0008-8846(01)00596-8.

[37] Bayasi, Z., Al Dhaheri, M. (2002). Effect of exposure to elevated temperature on polypropylene fiber reinforced concrete, ACI Materials Journal, 99(1), pp. 22-26. Available at: https://www.concrete.org/publications/internationalconcreteabstractsportal.aspx?m=details\&i=11312. 